\title{
Determinants of the production and profitability of audit services in Tunisia
}

\author{
Mouna Hamza ${ }^{1, a}$, Salma Damak ${ }^{\mathrm{a}}$ and Khaled Hussainey ${ }^{\mathrm{b}}$ \\ ${ }^{a}$ IHEC Carthage, University of Carthage, LIGUE, Tunisia. \\ ${ }^{b}$ Faculty of Business and Law, University of Portsmouth, Portsmouth, United \\ Kingdom.
}

\begin{abstract}
Purpose - This paper aims to identify the significant determinants of the production and profitability of audit services in Tunisia.

Design/methodology/approach - Based on a sample of 299 audit engagements from Tunisian audit firms and spanning the period from 2016 to 2018, the researchers used Ordinary Least Squares (OLS) regression estimation to test the research hypotheses. Subsequently, the researchers summarized the variables by using the Principal Component Analysis (PCA).

Findings - The study's findings show a positive association between client size and audit effort and, more specifically, larger clients are found to be more profitable to audit firms. Interestingly, larger specialized audit firms assign more audit hours and are less profitable. The findings show, also, that audit firms are likely to perform fewer audit hours when they rely heavily on the client's system and when the work is conducted during the busy season. Also, more audit effort is required when the engagement is a new one and when the firm previously provided the client with non-audit services.

Originality/Value - This study contributes to audit pricing literature by constructing models for the production and profitability of audit services by examining how a pre-determined audit fees framework affects an auditor's efforts and profits.
\end{abstract}

Keywords: Tunisia; Audit production; Audit profitability; Audit fees

\section{JEL Code: M42}

\footnotetext{
${ }^{1}$ Corresponding author: Mouna Hamza, IHEC Carthage, University of Carthage, LIGUE, Tunisia, Tel. (+216) 55135776, email addresses: mouna.hamza@ihec.u-carthage.tn
} 


\section{Introduction}

Complaints about high pricing and over auditing have arisen worldwide and, more particularly, about the Big 4 audit firms' excessive fees (McMeeking, 2007; DeFond \& Zhang, 2014; Stefaniak et al., 2017; Asare \& Wright, 2019; Martinis \& Houghton, 2019). Indeed, as an industry, audit firms strive for profits and, thus, undergo economic pressures to reduce costs while maintaining the quality of their services (Francis, 2011; Knechel, 2015). To provide competitive pricing for audit services, audit firms need information about the costs of a given audit engagement (Knechel et al., 2009).

This study aims to gain a better understanding of the determinants of the production and the profitability of audit services in Tunisia. The Tunisian context offers an interesting setting since audit fees are determined according to a pre-established scale whereby the auditors cannot influence the level of fees and, therefore, have no interest in over auditing. This facilitates using data from multiple audit firms since it suggests that the fees, charged by the audit firms, are computed based on the same scale.

However, as elsewhere, the challenges concerning data collection persist in Tunisia. Indeed, audit production studies require audit firms to provide confidential and private data which are not always available. Hence, when compared to audit pricing studies, there have been relatively few studies about the production of audits. In that respect, audit production studies rely on the audit pricing models applied in previous pricing studies.

Although the audit pricing model, firstly presented by Simunic (1980), has been widely used, it offers only indirect examinations of the assumptions made in audit production services. Namely, evidence, based on audit fees data, may be misleading since it may not be only due to changes in audit production but, also, to alterations in audit firms' pricing policies (O'Keefe et al., 1994).

In this study, we examined the determinants of audit production and profitability for 299 audit engagements during the period from 2016 to 2018. Our results show that the size of the audit client is the key attribute of audit hours and audit profitability. Our results provide, also evidence of the positive effect of audit firms' characteristics on audit efforts and their negative effects on audit profitability. Moreover, our results show, on the one hand, an association between audit engagement and auditor-client relationship and, on the other hand, an association between audit engagement and audit hours.

We contribute to the extant literature in at least two ways. First, our study's results complement previous research studies (O'Keefe et al., 1994; Hackenbrack \& 
Knechel, 1997) by exploring the audit firm's attributes, the engagement and the setting. Most of the existing studies have drawn on samples from one audit firm and, more especially, one of the Big 4 audit firms. However, in this study, we examine samples from North America and the United Kingdom Britain since little is known on how their insights can be generalized to other contexts. Consequently, we contribute to a more balanced international set of empirical evidence available for ongoing theory-building efforts. Second, by using a profitability measure that reflects the actual costs of engagement we contribute to the limited literature on audit profitability (Schelleman \& Knechel, 2010; Ciconte et al., 2015).

The remainder of the paper is organised as follows. Section 2 describes the specific features of the Tunisian audit environment. Section 3 outlines briefly previous related studies. Section 4 explains the research methodology. Section 5 discusses the empirical findings. Finally, Section 6 concludes the paper.

\section{Institutional background}

Two reasons justify the interest in studying the Tunisian setting. First, to date, accounting systems' studies within developing countries have focused more on standards and rules than on audit markets (market structure, pricing, etc.) (Khlif \& El Omari, 2015). Second, we are greatly interested in Tunisia's contemporary history and legal and institutional framework. The accounting rules are mainly the product of political negotiations dictated by politicians and government officials (El Omari $\&$ Khlif, 2014). Accounting has always served tax causes and government accounts.

Drawing on data from Tunisia offers several advantages when testing the total number of auditing hours allocated and audit profitability. According to the Tunisia's ${ } \mathrm{w}^{2}$, audit fees are not freely negotiated and depend on the sum of three components (the auditee's total income, gross balance-sheet total and the number of workers) ${ }^{3}$. Hence, the auditor's profit-maximization problem is reduced to one of minimizing the costs of conducting the audit given the fixed amount of fees to be paid. Because auditors cannot influence the level of fees and, accordingly, have no interest in over auditing, we consider that Tunisia provides us with a very good and interesting empirical setting to study this relationship.

Moreover, the Tunisian context facilitates the use of data from multiple audit firms since it suggests that they charge fees based on a pre-established scale. Hence, we do not need to fear that our findings may be influenced by differences in audit fees

\footnotetext{
2 The Decree of 28 February 2003 - The Order of the Minister of Finance

${ }^{3}$ For each component, we refer to the relative fraction within the scale. We retain the ceiling fees of the lower instalment, to which we add fees applied to the next portion. The result of the three-criteria is, then, cumulated.
} 
charged by the different audit firms, due to the clients' self-selection issues based on the level of fees of clients to auditors -levels. Accordingly, while the same challenges concerning data collection persist in Tunisia as elsewhere, the Tunisian context seems ideally suited to advance our understanding of the production and profitability of audit services.

Besides fixing the level of audit fees, the Tunisian legislation stipulates that auditors are not allowed to offer other services during the duration of their engagement to a client. This facilitates understanding the effects which are of interest to the researchers in this study since there is no possibility of any cross-selling and knowledge spillovers. Similarly, by law, auditor tenure runs for three years and is renewable only twice. Consequently, after having reached the maximum tenure period of nine years, an auditor must allow at least three consecutive years to elapse before being able to serve the same client again.

\section{Audit production services and audit profitability attributes: an overview of previous research}

In their meta-analysis, for ease of discussing the results, Hay et al. (2006) have identified three categories of factors that influence the audit fees. These are: namely, client attributes; auditor attributes; and engagement attributes. Hence, either explicitly or implicitly, all subsequent fees and production studies are based on this meta-analysis and, accordingly, include factors from these three categories in their models. Besides the three factors mentioned above, we consider contextual factors to explore the theoretical basis of the determinants of the production and profitability of audit services.

\subsection{Factors related to clients}

Previous studies' findings have shown that with the increase in the client size, more audit hours are allotted to the related audit engagement since there is a greater demand for substantive testing (O'Keefe et al., 1994; Schelleman \& Knechel, 2010; Aobdia et al., 2018). Hence, it is argued that larger entities require more audit effort which results in higher costs and fees (Simunic, 1980; Hay et al., 2006). The results of this attribute show that it accounts alone for more than $50 \%$ of the variation in audit fees (Bell et al., 1994). It has been also argued that the more complex the client's audit, the greater the difficulty and the greater the audit effort. Hence, these factors result in higher audit costs and fees (Simunic, 1980; Hackenbrack \& Knechel, 1997).

With regard to client's risk, Simunic (1980) and subsequent studies (Eilifsen et al., 2001; Bell et al., 2008; Akono \& Stein, 2014) have established that audit fees are sensitive to circumstances that increase an auditor's risk in engagement. This is 
because a certain area of the audit may present a higher risk of error. However, other studies have reported mixed results concerning the increase of inputted hours. While some studies find a link between an engagement risk and the allocation of labour (O'Keefe et al., 1994; Johnstone \& Bedard, 2001), others have failed to detect a relationship between risk and audit effort (Caramanis \& Lennox, 2008).

While previous studies (Bell et al., 1994; O'Keefe et al., 1994; Hackenbrack \& Knechel, 1997) have studied client characteristics as formed by its size, complexity and risk, we have added joint audit and audit fees to this category. This is because both depend on client size and significant accounts with important transactions flows. Although of a limited number, previous research studies have established the impact of joint audits on audit fees (Audousset-Coulier, 2015; André et al., 2016). Their findings show that there is a relationship between joint audits and significantly higher audit fees. However, there are still efforts to be made regarding the nature of the higher audit fees (mix of responsibilities, coordination, duplication, the amount of time spent on the audit engagement, etc.).

In his seminal paper, Simunic (1980) established a view of the audit production process. He measured audit production by using audit fees and he proposed a model which states that the audit fees are determined by some factors such as, the auditee size, risk and complexity. This is employed as a reference point when considering the phenomena surrounding the provision of audit services (Hay \& Knechel, 2010). Previous studies' findings show that the increase in audit fees arises solely from an increase in audit hours. This is because audit fees charged per hour are fixed (Bell et al., 2001; Schelleman \& Knechel, 2010). However, this observation is trivial since a modification in audit pricing does not reflect only a modification in audit production. Simunic (1980) has identified the following three factors that affect audit pricing: (1) factors of loss exposure; (2) determinants of the assessed loss-sharing between the auditor and the audit client; and (3) the economy realized through the production process. However, as fees are determined already according to a pre-established scale, the Tunisian context is of particular interest to the us in investigating the impact of audit fees on audit hours and the profitability of audit services. Hence, our first hypothesis is as follows:

H1.1. Client characteristics have a positive association with audit hours.

With regard to profitability, Schelleman \& Knechel (2010) assert that additional efforts may result either in higher audit pricing or more audit efforts or both. Hence, audit engagement may be more profitable for large entities bearing in mind that they charge higher audit prices and have lower expenses, i.e., engagement profitability relates significantly and positively to auditee size. However, Ciconte et al. (2015) findings fail to detect any association between auditee size and engagement profitability. Schelleman \& Knechel (2010) and Ciconte et al. (2015) findings demonstrate that complexity does not show a significant explanatory power of 
engagement profitability. When examining the risk of an audit engagement, Ciconte et al. (2015) findings show a negative association between inherent risk and profitability. This result may be due to the client's higher level of risk than that planned by the audit firm (Hackenbrack \& Hogan, 2005).

However, to the best of our knowledge, no previous research studies have tested the impact of a joint audit on the profitability of audit services. The association between audit pricing, audit hours, and audit profitability emerges in the Tunisian context. Indeed, when deciding to approve a new demand for the mandatory audit, an important issue is to verify whether expected fees are reasonable enough to cover the expected costs (Johnstone 2000). In fact, in a competitive market, audit pricing is negotiated to recover the expected auditor's costs increased by a normal profit (Bell et al., 2008).

Based on Schelleman \& Knechel (2010) findings, we expect client characteristics to have a positive effect on profitability. Consequently, our second hypothesis is as follows:

H1.2. Client size characteristics have a positive association with audit profitability.

\subsection{Factors related to the auditor}

Previous studies, which investigated the effect of office size on audit efforts and the profitability of audit services, have produced mixed results. The first stream of researchers' findings show that the Big4 audit firms perform more hours than NonBig4 firms as a justification for the higher quality of the supplied audit services (Becker et al., 1998). However, the second approach proves that, due to the economies of scale, large audit companies may benefit from cost advantages while producing the audit of similar engagements. For example, large audit firms are likely to include a larger pool of experienced auditors who can share their knowledge, understanding of a specific engagement's business operations and approach of internal control systems of different clients. This is why they assign auditors more efficiently (Choi et al., 2010).

According to Bonner (2008), auditor specialization allows for a specific industry learning through the generation of knowledge established across engagements. This learning results from the gains in cumulative audit production experience. Accordingly, specialization is used as a proxy for industry-specific knowledge (Palmrose, 1986b). Previous studies on audit industry learning have paid particular attention to the relationship between audit pricing and industry specialization (Dekeyser et al., 2018). Consequently, the audit industry specialization allows for price differentiation (Francis, 1984). Thereby, the paradigm of the industry learning curve implicates that the accumulated expertise, acquired from auditing several clients in a particular industry (significant industry scale), results in improved 
knowledge about a specific client's industry. Consequently, this leads to reduced marginal production costs, more efficient audits and fewer audit hours (Cabral \& Riordan, 1994; Besanko et al., 2010; Dekeyser et al., 2018). Mixed results have emerged about the relationship between audit industry knowledge and audit production: While Bae et al. (2016) claim that specialist auditors require higher fees and carry out more audit hours, Bills et al. (2015) support the idea that, because of the effects of industry learning, auditor industry specialization may be able to reduce audit hours. In sharing Bills et al. (2015) approach, we postulate a positive sign between auditor specialization and auditor profitability and a negative sign between auditor specialization and audit effort. Therefore, this hypothesis may be embedded within the theory of the cost and production function. Indeed, economies of scale, which are realized through audit firm size and specialization, are shown to have a negative association with audit hours (Choi et al., 2010; Dekeyser et al., 2018). Accordingly, we have formulated the following hypotheses:

H2.1. Auditor characteristics have a negative association with audit hours.

H2.2. Auditor characteristics have a positive association with audit profitability.

\subsection{Factors related to the engagement of the auditor}

Previous studies' findings points that, like learning that results from auditor tenure, non-audit services may generate lower audit fees and may produce economies of scale as an outcome of knowledge spillovers (Krishnan \& Yu, 2011). Indeed, synergies between audit and consulting services allow for the allocation of less effort on the audit Knowledge, which is reached when carrying out a specific client's nonaudit services, may "spill over" to the production of audit services through the reduction of audit hours and the generation of gains in production efficiencies (Simunic, 1984; Beck et al., 1988). While Simunic (1984) states that spillovers may result from performing both audit and consulting services during the same year, Beck et al. (1988) recognize that they may result from serving the audit client in previous years. However, audit production literature has failed to find a relationship between knowledge spillovers and audit hours (O'Keefe et al., 1994; Bell et al., 2008; Knechel, 2009).

The client's fiscal year-end is followed by the audit firms' busy season in January and February. Palmrose (1989) findings show that the time frame of the company year-end does not influence the number of hours engaged on an audit. However, Johnstone \& Bedard (2001) findings demonstrate that, although fees do not depend on the timing of the engagement, the number of audit hours has a strong influence at peak times since there may be possible reductions in the effort to carry out an audit. 
Interim work is the time spent by an audit team in performing audit engagement during the pre-final phase to reduce work during the busy season (Aobdia et al., 2018). Hence, firms, which carry out a portion of audit tasks before the actual yearend, focus, during the busy season, on whether or not the interim work achieved any important modifications in the client's financial position. Knechel et al. (2012) findings show that audit engagement, which allows enough time during the pre-final phase, achieves a better audit process and quality of financial reporting. They deduce that this finding is mainly the outcome of the time spent by the audit team. However, the question is whether the interim work has an impact on the hours of audit engagement and the profitability of audit services or is only a matter of how these hours are allocated. Having tested the impact of interim work on the number of hours spent on an audit, Knechel et al. (2009) findings show that there is no significant association. Accordingly, and bearing in mind the importance of Francis (2011) engagement-specific characteristics, we have formulated the following hypothesis:

H3.1. Engagement characteristics have a negative association with audit hours.

Turning to the profitability of audit services, Ciconte et al. (2015) have stated that there is no significant association between non-audit services and the profitability of audit services. Hay et al. (2006) anticipate a positive relationship between busy season and audit fees because, given that resources have to be allocated for working overtime, an audit, performed during peak periods, may be costlier.

In reporting that the year-end has a positive impact on auditor efficiency, Schelleman $\&$ Knechel (2010) findings show the same result. They argue that this may be due to the staff being more serious about their work during this critical period of the year. Therefore, auditors are constrained to be more efficient. In contrast, Ciconte et al. (2015) findings show a significant relationship between the busy season and the profitability of audit services. To the best of our knowledge, previous studies have not explored the impact of interim work on the profitability of audit services. Consequently, our second hypothesis is as follows:

H3.2. Engagement characteristics have a positive association with the profitability of audit services.

\subsection{Auditor-client relationship}

As with the inherent risk assessment, the internal control quality and degree of reliance measures characterize the auditor's whole strategy. According to Knechel \& Payne (2001), internal control is expected to affect audit pricing because the audit process should be sensitive to differences in the organization's control environment. Nonetheless, there have been reports of a lack of significant association between client control and the total number of hours spent working on an audit (O'Keefe et al., 1994; Hackenbrack \& Knechel, 1997; Schelleman \& Knechel, 2010). Lee \& Park 
(2016) provide evidence that auditors rely on internal control to improve audit efficiency. However, studies about the profitability of audit services have failed to find a significant relationship between the client's internal control and the profitability of engagement (Schelleman \& Knechel, 2010; Ciconte et al., 2015).

Auditor recurring tenure controls over time the learning process with the same client and it is assumed to be a source of economies of scale (Simunic 1980). In other words, an audit firm bears significant costs during the early years of the audit engagement to gain knowledge about the auditee's business. Consequently, learning over time, through repeated engagements, should have a negative effect on the number of hours spent on an audit. However, O'Keefe et al. (1994), Blokdijk et al. (2006) and Schelleman \& Knechel (2010) findings have demonstrated an unexpectedly significant and positive association between auditor tenure the number of hours spent on an audit. They justify their findings with the lack or the absence of learning.

Although Ciconte et al. (2015) findings predict a positive sign between first and second-year client and audit cost from one side, and a negative sign between this variable and audit profitability on the other, they fail to demonstrate a significant association in both relationships. Consequently, we predict that learning, acquired from the engagement tenure, has a negative sign on the production of an audit and a positive one on the profitability of audit services. Therefore, we have formulated the following two hypotheses:

H4.1. Auditor-Client relationship has a negative association with the number of hours spent on an audit.

H4.2. Auditor-Client relationship has a positive association with the profitability of audit services.

\subsection{Industry as a control variable}

The addition of industry to our analysis is motivated by previous studies' findings indicating that audit fees (hours) may vary across industries (Simunic, 1984; Palmrose, 1986a; Hay et al., 2006).

\section{Research methodology}

\subsection{Overview of the data gathering process}

We used a questionnaire to collect data and we based our design of the questionnaire on audit pricing and audit production studies. Although we took account of the reviewed literature in developing this survey instrument, we considered, also, 
Tunisia's regulations and legal texts governing the profession of statutory auditors. As a fundamental precondition, we reassured auditors that we did not need to be informed about the identity of the individual clients and that their answers would remain anonymous.

We divided the questionnaire into five sections. Section (A) consists of two questions. The first question lists the sectors to identify the engagement industry and Section (A) includes, also, a question related to the engagement's financial year on the understanding that it was conducted either during 2016 or the subsequent years. Section (B) encompasses 26 Yes-No questions on clients, auditors, and engagement characteristics. Section (C) includes a list of 19 questions divided into two categories These are: namely, (a) Three scale questions where participants are asked to make judgements (i.e. rating the complexity of the engagement, assessing the reliance on the client's internal control, and rating the perception of inherent risk) and (b) sixteen questions encompassing specific information from the balance sheet and the income statement which are intended to determine the audit fees and the client characteristics. To complete these questions, we asked the participants to retrieve the requested data from the client's financial statements, internal documents and the engagement timesheet. Based on the collected data, we calculated the fee based on Tunisian regulations. Section (D) incorporates a Table that aimed to collect information about the team assigned to the engagement. We asked the participants to enumerate the allocated auditors while communicating, among others, (a) their Rank, and (b) the Number of auditing hours spent on this engagement. Finally, to provide a descriptive analysis profile to supplement the findings, Section (E) includes five questions about the participants' background and demographic information (gender, age, rank, etc.). It encompasses, also, three questions about firm size. As regards the data on auditors' remunerations, given the sensitivity of the information needed on the one hand and the unified salaries per rank within each firm on the other, we collected this information separately. From part of our sample of each audit firm, we asked one auditor to provide us with the average billing rate per seniority in the audit firm while assuring them about the anonymity and the confidentiality of these data. Appendix B provides sample items of the questionnaire.

We paid great attention to collecting high-quality data. We accompanied our survey with guidelines specifying the selection criteria for the reported engagement so that it could be included in our database along with the instructions for completing the questionnaire. We conducted a pilot study to address issues about the questionnaire's validity. Before issuing the questionnaire, we tested the quality of the questions and statements to identify the presence of potential problems; to check the sequence of each question; and to further validate the number of questions. In designing the questionnaire, we focused, also, on its length, appearance, the formulation of the statements and the terms of the questions. 


\subsection{Sample and data}

The sampling unit is the statutory audit engagements performed during 2016 and the following years. We justified this target date through the fact that the Tunisian law governing the statutory auditors' profession was amended in March 2016. However, we focused only on engagements carried out by chartered accountants to ensure the conformity of the sample. Indeed, Tunisian chartered accountants and accountants in are not subject to the same scale of fees Table.

The selection criteria point that the engagements to be considered in the sample include: (1) financial statement of mandatory audits; (2) engagements performed during the period spanning the years from 2016 to 2018; (3) listed and unlisted companies subject to mandatory audit requirements; and (4) joint audit and non-joint audit engagements. The participants, representing audit firms, are auditors from different audit ranks from juniors to partners. The decision to include all seniorities is twofold. First, it enables us to increase the sample size. Second, the partners and managers tend to select their largest clients and inform about them. Therefore, the assigned team and the allocated effort refer to a specific circumstance. However, juniors and seniors provide data about the engagement in progress. For a faithful representation, we chose not to dismiss any rank. The auditors, participating in this study, represent auditors from large and small audit firms and, consequently, we can avoid audit firm-specific biases. Hence, our sample is the appropriate representation of the population. We know the identities of the audit firms included in our database. This is only needed to cross-reference them with the firms' average billing rate per seniority.

We received initially 357 completed questionnaires. We excluded surveys without the essential information needed to compute audit effort and/or missing data necessary for fees calculation. Consequently, we removed 51 incomplete questionnaires. We removed, also, the duplicated engagement of auditors who, unintentionally, had selected the same engagement. A cross-check of the answers received from auditors belonging to the same audit firm revealed seven doublecounted engagements. We ended up with a sample size of 299 completed questionnaires.

\subsection{Dependent variables}

\subsubsection{Audit hours}

Audit hours are a direct measure of audit effort. For example, Blokdijk et al. (2006) and Schelleman \& Knechel (2010) used aggregate audit hours. The sum of aggregated audit hours is the unweighted total of hours performed per each auditor assigned to a specific engagement. Following Schelleman \& Knechel (2010) 
example, we incorporated every individual who participated directly in the audit tasks (partner, manager, senior, assistant, supporting activities and trainee). It is worth mentioning that supporting activities and trainees do not belong to the audit firm's pyramidal organization and, commonly, are not members of the audit team. However, we included them in our study to offer a faithful representation of the audit firm's production process.

Following Ciconte et al. (2015) example, we considered the logarithm of sum hours. Consequently, our dependent variable corresponds to the logarithm of the total hours performed by an audit team.

\subsubsection{Audit profitability}

To assess the profitability of audit engagement, Schelleman \& Knechel (2010) Ciconte III \& Kitto (2019) opted for a direct measure of engagement profitability. They used the ratio of actual total audit fees paid by the client divided by the actual engagement cost.

We used the dictated audit scale fee to compute actual audit fees. The actual engagement cost is the result of multiplying the number of hours performed and reported by the auditors per ranks by the average billing rate per seniority in the audit firm. To compute the costs of an audit engagement, we multiplied the hours performed per each team member by the respective cost rate per hour of each rank. Then, we proceeded by summing over all auditors participating in the engagement. Furthermore, following Schelleman \& Knechel (2010) example, we added the outof-pocket costs (travel costs, lodging, and meals) to our findings.

Holding data on the average billing rate per ranks allows the profitability of the audit service to be measured by dividing total engagement fees by total engagement cost.

\subsection{Control variable}

We included client industry since it might have influenced audit effort and audit profitability. It is agreed that it is more difficult to conduct audits for some industries than others (Simunic, 1980; Palmrose, 1989; Pearson \& Trompeter, 1994). In compliance with the evidence on industry fee differences (Simunic, 1980; 1984; Pearson \& Trompeter, 1994) and production differences (Bell et al., 1994; Hackenbrack \& Knechel, 1997), financial audit entities require fewer labour hours than non-financial audit entities. Consequently, we suggest that financial entities have a negative coefficient. Appendix A below shows the specific variables that we used in our research models. 


\section{Data analysis and results}

\subsection{Descriptive Statistics}

Table 1 depicts descriptive statistics for the variables used in the empirical tests. Panel (A) presents dependent variables. The mean of audit hours is 831 ranging from 26 to 7280 hours. The mean of profitability is 3.108 , although the engagement profitability figures are dispersed with a minimum and a maximum of 1.154 and 19.623 respectively. Based on the descriptive statistics, audit engagements are consistently profitable or even very profitable. Ciconte et al. (2015) findings show that, on average, only 0.96 of the engagements' costs are recovered. Schelleman \& Knechel (2010) findings show, on average, a small fee premium (1.02 of the engagement' costs are covered). However, the comparison is irrational given the contextual differences.

Table 1's (Panel A) results reveal that, on average, the audit fee per engagement is 27,013.56 TND with a minimum of $1,700 \mathrm{TND}$, which corresponds to the lowest legal fees, and a maximum of 128,773 TND. The mean number of auditors within an office is 70 auditors with a maximum of 120 and a minimum of 3 auditors within the same office. This can be attributed to the fact that our sample encompasses large and small audit firms.

Table 1's (Panel B) results show that about $21 \%$ of the firms are listed on the Tunisian stock exchange; only $4.3 \%$ of the clients within our database have their auditor for the first year; and about $36 \%$ of our sample received non-audit services previously from their audit firm.

In relation to engagement characteristics, we show that about $46 \%$ of all the engagements consist of joint audit and that more than $75 \%$ of the engagements in the sample are carried out during the peak period $(76,5 \%)$. However, the firms perform interim work quite often (71.2\%).

Table 1. Descriptive Statistics

\begin{tabular}{|c|c|c|c|c|c|c|}
\hline & Obs. & Mean & Median & S.D. & Min & $\operatorname{Max}$ \\
\hline \multicolumn{7}{|c|}{ Panel A- Dependent variables } \\
\hline Hours & 299 & 831.103 & 544 & 841.901 & 26 & 7280 \\
\hline $\mathrm{P}$ & 299 & 3.108 & 2.651 & 2.32 & 1.154 & 19.623 \\
\hline \multicolumn{7}{|c|}{ Panel B - Independent variables } \\
\hline Assets & 299 & $464,062.7$ & 57,600 & 127,7793 & 8.074 & $82,429.17$ \\
\hline Fees & 299 & $27,013.56$ & $20,709.77$ & $22,895.13$ & 1,700 & 128,773 \\
\hline Aud_Size & 299 & 70 & 75 & 44 & 3 & 120 \\
\hline Complexity & 299 & 4.1 & 4 & 1.448 & 1 & 7 \\
\hline
\end{tabular}




\begin{tabular}{lcccccr}
\hline & Obs. & \multicolumn{1}{l}{ Mean } & Median & S.D. & Min & \multirow{2}{*}{ Max } \\
\hline Public & 299 & 0.214 & 0 & 0.410 & 0 & 1 \\
New_Clt & 299 & 0.043 & 0 & 0.204 & 0 & 1 \\
ICreliance & 299 & 0.140 & 0 & 0.348 & 0 & 1 \\
Aud_Spec & 299 & 0.274 & 0 & 0.446 & 0 & 1 \\
Nas_P & 299 & 0.367 & 0 & 0.483 & 0 & 1 \\
Joint_Aud & 299 & 0.461 & 0 & 0.499 & 0 & 1 \\
Peak & 299 & 0.765 & 1 & 0.424 & 0 & 1 \\
Interim & 299 & 0.712 & 1 & 0.453 & 0 & 1 \\
Industry & 299 & 0.153 & 0 & 0.361 & 0 & 1 \\
\hline
\end{tabular}

Note: All variables are defined in Appendix A

\subsection{Correlation analysis}

To verify if the independent variables suffer from multicollinearity problems, we established a correlation matrix. As derived from the correlation matrix. The results show a correlation coefficient between the audit fees variable (ln fees) and that of the client size (ln assets) below 0.8 . The intercorrelation between these two variables is to be expected because the client assets attribute is one of the three determinants of the fee calculation scale. Moreover, previous studies' findings have established the link between audit fees and client size (Schelleman \& Knechel, 2010; Bradbury \& Botica Redmayne, 2014). However, the multicollinearity problem may make our model biased.

When this problem emerges, various corrective measures can be engaged; for example, the one most commonly used is the deletion of one of the predictors causing the trouble. However, it is not possible to remove client size from our analysis since it has been used in almost all previous production studies and has been shown to explain alone more than $50 \%$ of the cross-section variability in audit fees (Bell et al., 1994). To overcome the problem of the correlation matrix, we used Principal Component Analysis (PCA) as a summarizing method.

\subsection{Derived components as an alternative to the correlation problem}

PCA aims at data reduction since it is used to replace multivariate data with fewer components that reflect as much information as possible. According to Hatcher \& Stepanski (1994), the PCA application assumptions, such as the determinant of the matrix, the Bartlett test, and the overall measure of sampling adequacy (KaiserMeyer-Olkin test), needed to be satisfied. 
As can be seen in Table 2, the Kaiser-Meyer-Olkin (KMO) measure indicates a value of 0.747 . The Bartlett's sphericity tests data suitability for reduction and rejects the null hypothesis of equality of variances ( $\mathrm{p}$-value $=0.000$ ); this suggests that the variances are unequal for at least two groups. The results (Table 2) show that the estimated statistics encourage us to continue the use of PCA.

Table 2. Application Conditions of Principal Component Analysis

\begin{tabular}{l|l}
\hline Chi $^{2}$ (Observed) & 1548.262 \\
Bartlett (Degree of freedom) & 78 \\
P-value Unilateral & 0.000 \\
Correlation Matrix Determinant & 0.005 \\
Kaiser-Meyer-Olkin & 0.747 \\
\hline
\end{tabular}

Notes: This table reports the conditions of Principal Component Analysis

Given that PCA is a data reduction method, it is necessary to retain an appropriate number of components simultaneously to allow the retention of as fewer factors as possible and the explanation of the maximum of data variation. Following the KMO rule, we retained components resulting from PCA with eigenvalues greater than one. This resulted in four components. Table 3 reports the derived components. The variance of our factors presents almost $61.6 \%$ of the total variance.

Next, we applied oblique rotation to enable the retained components to be correlated in order to reach more meaningful axes and to enhance the interpretation of the results. The rotation process maintains the relative relationships between variables. Each component is expressed as a linear combination of discriminating variables with standardized coefficients. Hence, we obtained four discriminant functions through four axes.

Table 3. PCA Results

\begin{tabular}{lcccr}
\hline & PC1 & PC2 & PC3 & PC4 \\
\hline Eigenvalue & 4.293 & 1.589 & 1.076 & 1.036 \\
\% Proportion & 0.330 & 0.122 & 0.085 & 0.080 \\
\% Cumulative & 0.330 & 0.451 & 0.536 & 0.616 \\
\hline
\end{tabular}

Note: This table shows the PCA results. Four factors have been retained following an orthogonal oblimin rotation. PC1: Principal component 1; PC2: Principal component 2; PC3: Principal component 3; PC4: Principal component 4.

\section{- Axis 1 - Client size}

The first component "PC1" is the most significant axis since it accounts for the maximum of variance $(\mathrm{PC} 1=33 \%)$. It can be expressed as follows:

$$
P C 1=0.43 \text { Lnassets }+0.42 \text { Lnfees }+0.454 J \text { int_Aud }
$$




\section{-Axis 2 -Auditor characteristics}

Each subsequent component reflects information that has not been reflected by the first one. It must have the highest variance and must not be correlated with the preceding components. Hence, PC 2 represents $12 \%$ of the variance and is correlated with auditor size and specialization variables. Therefore, this axis characterizes the audit firm and is given as follows:

$$
\text { PC } 2=0.564 \text { Audit_Size }+0.744 \text { Audit_Spec }
$$

\section{-Axis 3 - Engagement characteristics}

Non-audit services performed previously to a given client and the busy season shaped our third principal component characterizing a specific engagement. It reflects $8.5 \%$ of the variance. This axis discriminant function is stated as follows:

$$
P C 3=0.698 N a s_{-} P-0.599 P e a k
$$

\section{-Axis 4-Auditor-Client relationship}

This fourth axis includes internal control reliance, new client, and accounts for $8 \%$ of the variance. This axis is rather oriented towards client trust, reliance, and knowledge spillovers. Therefore, our fourth linear combination is as follows:

$$
\text { PC } 4=-0.577 \text { ICreliance }+0.643 \text { New_Clt }
$$

The thirteen variables identified within the literature review are reduced to four components when the PCA is applied. Henceforth, the four identified components replace our original variables.

\subsection{Regression analyses}

After checking for OLS assumptions, we examine the determinants of audit production and audit profitability by running an Ordinary Least Square (OLS) regression estimation.

Lnh $i=\beta_{0}+\beta_{1}$ Clientcharacteristicsi $+\beta_{2}$ A uditorcharacteristicsi $+\beta_{3}$ Engagementcharacteristicsi

$+\beta_{4}$ A uditor - Clientrelationship $i+\varepsilon_{l}$

$P_{i}=\beta_{0}+\beta_{1}$ Clientcharacteristics $i_{i}+\beta_{2}$ Auditorcharacteristics $i+\beta_{3}$ Engagementcharacteristics $i_{i}$

$+\beta_{4}$ A uditor - Clientrelationship $i+\varepsilon_{l}$

Vol. 20, No. 2 
With:

$L n h_{i}=$ Ln total audit hours

$P_{i}=$ Engagement profitability

Clientcharacteristics $i=0.43$ Lnassets +0.42 Lnfees $+0.454 J o$ int_Aud

Auditorcharacteristics ${ }_{i}=0.564$ Audit_Size +0.744 Audit_Spec

Engagementcharacteristics $i=0.698 N a s_{-} P-0.599$ Peak

Auditor - Clientrelationship $i=-0.577$ ICreliance $+0.643 \mathrm{New} \_$Clt

$\varepsilon_{\mathrm{i}}$ : the error term

Table 4. Regression Results of Audit Effort and Audit Profitability Models

\begin{tabular}{|c|c|c|c|c|}
\hline \multirow[b]{2}{*}{ Components } & \multicolumn{2}{|c|}{ Model 1} & \multicolumn{2}{|c|}{ Model 2} \\
\hline & Coef. & P-value & Coef. & P-value \\
\hline PC1 & $0.409 * * *$ & $(0.000)$ & $0.255^{* *}$ & $(0.014)$ \\
\hline PC2 & $0.007 * * *$ & $(0.000)$ & $-0.017 * * *$ & $(0.005)$ \\
\hline PC3 & $0.190 * *$ & $(0.017)$ & 0.265 & $(0.358)$ \\
\hline PC4 & $0.283 * *$ & $(0.013)$ & 0.099 & $(0.809)$ \\
\hline Constant & $2.471 * * *$ & $(0.000)$ & 1.518 & $(0.167)$ \\
\hline $\begin{array}{r}\text { R-squared } \\
(\%)\end{array}$ & \multicolumn{2}{|c|}{57.5} & \multicolumn{2}{|c|}{33.3} \\
\hline Obs. & \multicolumn{2}{|c|}{299} & \multicolumn{2}{|c|}{299} \\
\hline
\end{tabular}

Notes: This Table reports OLS regression estimation. The dependent variable Lnh=Lnhours, $\mathbf{P}=$ Profitability. The independent components PC1: Client characteristics; PC2: Auditor characteristics; PC3: Engagement characteristics; PC4: Auditor-Client relationship. The significance levels (two-tail test) are: $*=10 \%, * *=5 \%$ and $* * *=1 \%$.

Table 4 depicts the results of the tests of our hypotheses related to audit effort and audit profitability. Pairwise correlation and variance-inflation factors among the four components (not reported) indicate that multicollinearity is not a problem. The overall models are significant ( $\mathrm{p}=0.000$ and $\mathrm{p}<0.005$, respectively): The $\mathrm{R}^{2}$ for the effort model is $\mathbf{5 7 . 5}$ and is comparable to previous studies (O'Keefe et al., 1994; Blokdijk et al., 2006), and the $\mathrm{R}^{2}$ for the profitability model is 33.3. This is comparable to the results of Schelleman \& Knechel (2010) and Ciconte et al. (2015) findings (the $\mathrm{R}^{2}$ is 30.9 and 30.9 , respectively). Moreover, the explanatory power of the ratio model tends to be lower (Kothari, 2001). 
As expected, client size component (Lnassets, Lnfees and Joint_Aud) is significant and positive at the $1 \%$ and $5 \%$ levels in the first and the second models respectively. The finding of the first model is in line with those of previous studies on such an association. Indeed, Bell et al. (1994) findings show that client size controls the quantity of audit effort. Although Lnassets is the proxy used by most previous studies to test for the effect of size on audit production, Lnfees and Joint_Aud provide evidence to be part of the same component.

Turning to the second model, we find that higher profitability is associated with larger clients. This finding can be explained by the fact that large client audits result in higher audit fees than the additional amount of audit effort. Therefore, both hypotheses, H1.1 and H1.2, are accepted.

Table 4's results (Models 1 and 2) provide evidence of a significant association between auditor characteristics and audit effort and profitability at the level of $1 \%$. Based on microeconomic logic to explore audit production and audit profitability, we presume that auditors perform with the intention of maximising their profit (Watts \& Zimmerman, 1986). Subsequently, relying on Choi et al. (2010) inferences, we suggest a negative sign for the first model and a positive one for the second. However, surprisingly, both results contradict our assumptions.

Indeed, auditor characteristics are positively associated with audit hours: i.e., that a larger and more specialized audit company carries out more audit hours. Similarly, when examining the effect of auditor characteristics (size and specialization) on audit profitability, we demonstrate, contrary to our expectations, that auditor size and specialization have a negative effect on profitability.

These findings are in line with those of Bae et al. (2016) who demonstrated that audit effort associated with auditor specialization is likely to require greater audit hours. In the same vein, Becker et al. (1998) findings show that the Big 4 audit firms legitimize a higher audit quality by increasing audit effort amount.

These results have two possible explanations. First, by performing more audit hours, large audit firms highlight the worth of their services and focus on their reputation rather than profitability. Larger audit firms are more careful about the rank specific task assignment and the team composition. Hence, this signals high audit quality (Scott \& Gist, 2013). However, a raise within partners and managers hours generates an increase of the engagement cost (Hackenbrack \& Knechel, 1997). Second, an interviewed auditor drew our attention to the heavy audit process carried out by auditors working for large audit firms (for example, documentation) and the relatively costlier auditors assigned by large firms compared to cheaper juniors performing within smaller ones. Accordingly, contrary to our expectations, our results do not support hypotheses $\mathrm{H} 2.1$ and $\mathrm{H} 2.2$ and, therefore, these are rejected. 
In the first model, the association between engagement characteristics and audit effort is positive and significant at the 5\% level. The sign of the association itself is meaningless. Indeed, the third component includes two variables: namely, non-audit services (Nas_P) performed previously to a client; and the performance of audit hours during the busy season (Peak). While the first one is positive, the second one displays a negative sign. The coefficient estimates of Lnhours are 0.133 and 0.114 , respectively.

In accordance with Johnstone \& Bedard (2001) and Schelleman \& Knechel (2010), we document that the year-end has a negative influence on audit effort. Reduced audit hours performed to realize an audit engagement may be explained through the high demand for audit services during this critical period of the year.

The auditor, concerned by his reputation, does not take the risk to reduce audit effort necessary to the accomplishment of a specific engagement. From an economic perspective, the provider of the audit services is a rational agent. Auditors may carry out working on the engagement at home or during the weekend to preserve the level of hours needed.

Although previous related studies (O'Keefe et al., 1994; Bell et al., 2008; Schelleman \& Knechel, 2010) failed to provide evidence of knowledge spillovers through nonaudit services provided to the same client, we demonstrate a negative and significant sign. This may be because clients, who request non-audit services, may be problematic generally (Hay et al., 2006). Furthermore, our discussions with auditors providing the data indicate that the learning, which results from knowledge spillovers is conditional. Among others, the audit team, assigned to both non-audit services and mandatory audit engagement, should be the same to the maximum extent possible.

As can be seen from Table 4, there is a lack of significant association between the third component and the measure of the auditor's ability to recover the full cost. Overall, our findings are in line with Ciconte et al. (2015) in that they indicate the busy season and non-audit services variables do not provide any incremental explanatory power when they are included in the audit profitability model. Consequently, hypotheses H3.1 and H3.2 are rejected.

Turning to the fourth component, our results reveal that there is a positive relationship between auditor-client and audit effort at the 5\% level. This component includes the reliance on the client's internal control besides performing new engagements when the auditor explores the client environment. However, the two variables, which shape the auditor-client relationship, are of opposite signs: the reliance on client internal control (ICreliance) is positive whereas performing a new engagement (New_Clt) is negative. The coefficient estimates of Lnhours are 0.163 and 0.182 respectively. 
Although previous studies' findings about audit production (O'Keefe et al., 1994; Hackenbrack \& Knechel, 1997; Schelleman \& Knechel, 2010) do not demonstrate the expected negative effect of client controls on audit effort, our findings show that the audit process is sensitive to the auditor's reliance on client control. Indeed, the more the auditor trusts the client's internal control system, the lesser the allocation of audit effort.

Likewise, and in accordance with previous research (Caramanis \& Lennox, 2008; Knechel et al., 2009) predictions regarding the assignment of more audit effort during the first year than the subsequent years, we document a positive association between new client engagement and audit hours. However, it is noteworthy that this finding is inconsistent with the findings of previous studies.

When considering the association between auditor-client relationship and audit profitability, the coefficient of the fourth component (ICreliance and New_Clt) is insignificant at its conventional level. Audit profitability studies (Schelleman \& Knechel, 2010; Ciconte et al., 2015) fail, also, to find a significant association between the client's internal control and the profitability of engagement. Therefore, while hypothesis H4.1 is accepted, hypothesis H4.2 is rejected.

\subsection{Supplementary analysis}

Having analyzed the determinants of audit effort and audit profitability, we focus on audit cost as a critical element of the production of the audit.

Table 5. Regression Results of Audit Cost Model

\begin{tabular}{ccc}
\hline Components & Coef. & P-value \\
\hline PC1 & $0.404^{* * *}$ & $(0.000)$ \\
PC2 & $0.004^{* *}$ & $(0.024)$ \\
PC3 & $0.196^{* *}$ & $(0.018)$ \\
PC4 & 0.194 & $(0.101)$ \\
Constant & $5.425^{* * *}$ & $(0.000)$ \\
R-squared (\%) & & 50.6 \\
Obs. & & 299 \\
\hline
\end{tabular}

Notes: This Table reports OLS regression estimation. The dependent variable Lntcost=Ln toal cost. The independent components PC1: Client size; PC2: Auditor characteristics; PC3: Engagement characteristics; PC4: Auditor-Client relationship. The significance levels (two-tail test) are: $*=10 \%, * *=5 \%$ and $* * *=1 \%$. 
Given that the level of audit effort can be adjusted either through performing more hours or through assigning more experienced and costlier auditors (Schelleman \& Knechel, 2010), we find it interesting to examine the determinants of audit cost.

Indeed, by investigating audit cost, we examine the cost of the time devoted to a specific audit. This allows us to better understand the reasons for the increase in profitability. We predicted that the components of the cost model would display the same coefficient as the audit effort model because the overall increase in the cost of an engagement is assumed to derive from the combined effect of a high amount of audit effort and/or more expensive audit hours.

As can be seen from Table 5, the overall model is significant $(\mathrm{p}=0.000)$ and has an adjusted $\mathrm{R}^{2}$ equal to $50.6 \%$. However, the results of the audit effort are more robust than those related to cost. The findings confirm a positive correlation at the level of $1 \%$ (a coefficient of 0.404 ) between the client size component and audit cost. This last result is in line with that of the audit hours model.

The auditor characteristics component is significant at the level of 5\% and, contrary to our expectations, is positive. Although the estimated coefficient is low (0.004), these results further strengthen the presented argument within the audit hour model analysis. Large audit firms do care about their reputations and the relatively costlier auditors assigned to a specific engagement compared to cheaper junior performing the work within the smaller firms (Bae et al., 2016). This explains our finding.

Unlike Ciconte et al. (2015) who failed to find a significant association, we document that audit engagement is significant and positive at the conventional level when testing for audit hours. Indeed, we observe higher engagement costs related to the client who has received previously non-audit services since more hours are assigned on the basis that he may be problematic. However, as explained earlier, the total cost of hours declines during the busy season due to the reduction in the number of assigned hours assigned.

When examining the effect of the fourth component on the audit cost, we expected the same finding as audit effort. However, we document that the auditor-client component does not affect the cost of a specific engagement (see Table 5). We have no explanation for this result.

\section{Conclusion}

Based on previous audit fees and production literature, we examined the determinants of the production of audits and the profitability of audit services in Tunisia, where audit fees are regulated by law. Hence, this presents an interesting 
institutional setting. In the Tunisian context, this legal provision is a special feature. Indeed, only another country (Togo) is known to have a similar regulation.

Focusing on a sample of 299 audit engagements over the period from 2016 to 2018, we give evidence of a positive association between client size and engagement in the production and profitability of audit services. Our finding is consistent with previous literature on the relationship between client characteristics and the amount of assigned labour and the achieved profit (O'Keefe et al., 1994; Schelleman \& Knechel, 2010). More particularly, our results show that client size is the key attribute of audit firm characteristics leading to an increase in audit effort. Taking account of audit firm characteristics, we document that the variations in audit effort and audit profitability are not driven solely by client size. However, our findings are contrary to our expectations. This may be due either to the level of provided audit quality (Scott \& Gist, 2013) or to the cost they bear. Additionally, while a higher reliance on client's system and performing the engagement during the busy season result in less audit effort, performing a new engagement and non-audit services previously lead to more audit hours.

Our study complements existing literature in several ways. First, by exploring new attributes within a particular context, we go beyond the rare previous studies on the determinants of the production and profitability of audit services. Consequently, we attempt to model the assigned effort and the profit achieved in performing an audit. Moreover, by drawing on a representative sample (including both Big and Non-Big4 audit firms), we overcame the limited range of data encountered by previous studies (O'Keefe et al., 1994; Ciconte et al., 2015). The reported findings have practical implications for auditors and clients to compete effectively based on the effort provided and the amount of effort needed to both achieve a specific audit engagement and assess the audit quality.

This study has some limitations: First, although fees are predetermined within the Tunisian context, some practices, such as "low-balling", time underreporting, etc., if existent, may alter our data and, consequently, our results. Second, although labour costs are assumed to be the most significant component within audit firms, fixed costs may vary across firms. Also, the mix of audit hours has to be taken into consideration.

Based on the profession specificities as distinctive elements, which differentiate it from other industries (Brierley \& Gwilliam, 2003), audit firms provide a special context for studying the decisions made in allocating resources. However, although audit is examined as a production service, inputs to the audit process cannot be determined only in quantitative terms (Knechel et al., 2013). 


\section{References}

Akono, H. \& Stein, M. (2014) "Estimating audit fees and production models", The Routledge Companion to Auditing, edited by Hay, Knechel and Willekens", Routledge.

André, P., Broye, G., Pong, C. \& Schatt, A. (2016) "Are joint audits associated with higher audit fees?", European Accounting Review, vol. 25, no. 2: 245-274.

Aobdia, D., Choudhary, P. \& Newberger, N. (2018) "Which Audit Input Matters? An Analysis of the Determinants of Audit Quality, Profitability, and Audit Fees Using PCAOB Data", vol. 12, Available at SSRN : https://papers.ssrn.com/sol3/papers.cfm?abstract_id=3300277.

Asare, S.K. \& Wright, A.M. (2019) "The effect of a prompt to adopt the prudent official's perspective on auditors' judgments of the severity of control deficiencies", Auditing: A Journal of Practice \& Theory, vol. 38, no. 4: $1-16$.

Audousset-Coulier, S. (2015) "Audit fees in a joint audit setting", European Accounting Review, vol. 24, no. 2: 347-377

Bae, G.S., Choi, S.U. \& Rho, J.H. (2016) "Audit hours and unit audit price of industry specialist auditors: Evidence from Korea", Contemporary Accounting Research, vol. 33, no. 1: 314-340

Beck, P.J., Frecka, T.J. \& Solomon, I. (1988) "An empirical analysis of the relationship between MAS involvement and auditor tenure: Implications for auditor independence", Journal of Accounting Literature, vol. 7, no. 1: 65-84.

Becker, C.L., DeFond, M.L., Jiambalvo, J. \& Subramanyam, K. (1998) "The effect of audit quality on earnings management", Contemporary Accounting Research, vol. 15 , no. 1: 1-24.

Bell, T.B., Doogar, R. \& Solomon, I. (2008) "Audit labor usage and fees under business risk auditing", Journal of Accounting Research, vol. 46, no. 4: 72960 .

Bell, T.B., Knechel, W.R. \& Willingham Jr, J.J. (Year) of Conference, "An exploratory analysis of the determinants of audit engagement resource allocations", Auditing Symposium XII: Proceedings of the 1994 Deloitte \& Touche/Kansas Symposium on Auditing Problems, pp. 49-67.

Bell, T.B., Landsman, W.R. \& Shackelford, D.A. (2001) "Auditors' perceived business risk and audit fees: Analysis and evidence", Journal of Accounting research, vol. 39, no. 1: 35-43.

Besanko, D., Doraszelski, U., Kryukov, Y. \& Satterthwaite, M. (2010) "Learningby-doing, organizational forgetting, and industry dynamics", Econometrica, vol. 78 , no. 2: 453-508.

Bills, K.L., Jeter, D.C. \& Stein, S.E. (2015) "Auditor industry specialization and evidence of cost efficiencies in homogenous industries", The Accounting Review, vol. 90, no. 5: 1721-1754. 
Blokdijk, H., Drieenhuizen, F., Simunic, D.A. \& Stein, M.T. (2006) "An analysis of cross-sectional differences in big and non-big public accounting firms' audit programs", Auditing: A Journal of Practice \& Theory, vol. 25, no. 1: 27-48.

Bonner, S.E. (2008) Judgment and decision making in accounting, Pearson, Prentice Hall, Upper Saddle River, NJ.

Bradbury, M.E. \& Botica Redmayne, N. (2014) "Audit effort and pricing differences among the large audit firms: Evidence from a public sector setting", International Journal of Auditing, vol. 18, no. 1: 90-100.

Brierley, J.A. \& Gwilliam, D.R. (2003) "Human resource management issues in audit firms: A research agenda", Managerial Auditing Journal, vol. 18: $431-438$

Cabral, L.M. \& Riordan, M.H. (1994) "The learning curve, market dominance, and predatory pricing", Econometrica: Journal of the Econometric Society: 1115-1140.

Caramanis, C. \& Lennox, C. (2008) "Audit effort and earnings management", Journal of accounting and economics, vol. 45, no. 1: 116-138.

Choi, J.-H., Kim, C., Kim, J.-B. \& Zang, Y. (2010) "Audit office size, audit quality, and audit pricing", Auditing: A Journal of practice \& theory, vol. 29, no. 1: 73-97.

Ciconte III, W.A. \& Kitto, A.R. (2019) "Profit persistence in the US audit market", https://pdfs.semanticscholar.org/3a92/fdaa8069206b7575647cfb0c4a5199c 938f9.pdf.

Ciconte, W., Knechel, W.R. \& Schelleman, C. (2015) "An examination of the relation between market structure and the profitability of audit engagements", Accounting \& Finance, vol. 55, no. 3: 749-781.

DeFond, M. \& Zhang, J. (2014) "A review of archival auditing research", Journal of accounting and economics, vol. 58, no. 2-3: 275-326.

Dekeyser, S., Gaeremynck, A. \& Willekens, M. (2018) "Evidence of industry scale effects on audit hours, billing rates, and pricing", vol. 36: 666-693.

Eilifsen, A., Knechel, W.R. \& Wallage, P. (2001) "Application of the business risk audit model: A field study", Accounting Horizons, vol. 15, no. 3: 193-207.

Ettlie, J.E., Bridges, W.P. \& O'keefe, R.D. (1984) "Organization strategy and structural differences for radical versus incremental innovation", Management Science, vol. 30, no. 6: 682-95.

Francis, J.R. (1984) "The effect of audit firm size on audit prices: A study of the Australian market", Journal of Accounting And Economics, vol. 6, no. 2: 133-151.

Francis, J.R. (2011) "A Framework for Understanding and Researching Audit Quality", Auditing: A Journal of Practice \& Theory, vol. 30, no. 2: 125-152

Hackenbrack, K. \& Knechel, W.R. (1997) "Resource allocation decisions in audit engagements", Contemporary Accounting Research, vol. 14, no. 3: 481-99.

Hackenbrack, K.E. \& Hogan, C.E. (2005) "Client retention and engagement-level pricing", Auditing: A Journal of Practice \& Theory, vol. 24, no. 1: 7-20. 
Hatcher, L. \& Stepanski, E.J. (1994) A step-by-step approach to using the SAS system for univariate and multivariate statistics, SAS Institute Inc., Cary, $\mathrm{NC}$.

Hay, D., Knechel, R. \& Li, V. (2006) "Non-audit services and auditor independence: New Zealand evidence", Journal of Business Finance \& Accounting, vol. 33, no. 5-6: 715-34.

Hay, D. \& Knechel, W.R. (2010) "The effects of advertising and solicitation on audit fees", Journal of Accounting and Public Policy, vol. 29, no. 1: 60-81.

Hay, D.C., Knechel, W.R. \& Wong, N. (2006) "Audit fees: A meta-analysis of the effect of supply and demand attributes", Contemporary Accounting Research, vol. 23, no. 1: 141-91.

Johnstone, K.M. (2000) "Client-acceptance decisions: Simultaneous effects of client business risk, audit risk, auditor business risk, and risk adaptation", Auditing: A Journal of Practice \& Theory, vol. 19, no. 1: 1-25.

Johnstone, K.M. \& Bedard, J.C. (2001) "Engagement planning, bid pricing, and client response in the market for initial attest engagements", The Accounting Review, vol. 76, no. 2: 199-220.

Khlif, W. \& El Omari, S. (2015) "Expertise comptable en Tunisie", La Revue des Sciences de Gestion, no. 3: 47-55.

Knechel, W.R. (2009) "Audit lessons from the economic crisis: Rethinking audit quality", Maastricht University Maastricht, The Netherlands.

Knechel, W.R. (2015) "Audit research in the wake of SOX", Managerial Auditing Journal, vol. 30, no. 8-9: 706-26.

Knechel, W.R., Krishnan, G.V., Pevzner, M., Shefchik, L.B. \& Velury, U.K. (2013) "Audit quality: Insights from the academic literature", Auditing: A Journal of Practice \& Theory, vol. 32, no. sp1: 385-421.

Knechel, W.R. \& Payne, J.L. (2001) "Additional evidence on audit report lag", Auditing: A Journal of Practice \& Theory, vol. 20, no. 1: 137-46.

Knechel, W.R., Rouse, P. \& Schelleman, C. (2009) "A Modified Audit Production Framework: Evaluating the Relative Efficiency of Audit Engagements", The Accounting Review, vol. 84, no. 5: 1607-1638.

Knechel, W.R., Sharma, D.S. \& Sharma, V.D. (2012) "Non-audit services and knowledge spillovers: Evidence from New Zealand", Journal of Business Finance \& Accounting, vol. 39, no. 1-2: 60-81.

Kothari, S. (2001) "Capital markets research in accounting", Journal of Accounting and Economics, vol. 31, no. 1-3: 105-231.

Krishnan, G.V. \& Yu, W. (2011) "Further evidence on knowledge spillover and the joint determination of audit and non-audit fees", Managerial Auditing Journal, vol. 26, no. 3: 230-247.

Lee, H.-Y. \& Park, H.-Y. (2016) "Characteristics of the internal audit and external audit hours: evidence from S. Korea", Managerial Auditing Journal, vol. 31, no. 6/7: 629-54.

Martinis, M.D. \& Houghton, K. (2019) "The business risk audit approach and audit production efficiency", Abacus, vol. 55, no. 4: 734-782. 
McMeeking, K.P. (2007) "Competition in the UK accounting services market", Managerial Auditing Journal, vol. 22, no. 2: 197-217.

O'Keefe, T.B., Simunic, D.A. \& Stein, M.T. (1994) "The production of audit services: Evidence from a major public accounting firm", Journal of Accounting Research, vol. 32, no. 2: 241-261.

Palmrose, Z.-V. (1986a) "Audit fees and auditor size: Further evidence", Journal of accounting research, vol. 24: 97-110.

Palmrose, Z.-V. (1986b) "The effect of nonaudit services on the pricing of audit services: Further evidence", Journal of Accounting Research, vol. 24: 405411.

Palmrose, Z.-V. (1989) "The relation of audit contract type to audit fees and hours", Accounting Review, July: 488-499.

Pearson, T. \& Trompeter, G. (1994) "Competition in the market for audit services: The effect of supplier concentration on audit fees", Contemporary Accounting Research, vol. 11, no. 1: 115-135.

Schelleman, C. \& Knechel, W.R. (2010) "Short-term accruals and the pricing and production of audit services", Auditing: A Journal of Practice \& Theory, vol. 29, no. 1: 221-250.

Scott, W.R. \& Gist, W.E. (2013) "Forced auditor change, industry specialization and audit fees", Managerial Auditing Journal.

Simunic, D.A. (1980) "The pricing of audit services: Theory and evidence", Journal of accounting Research, vol. 18: 161-190.

Simunic, D.A. (1984) "Auditing, consulting, and auditor independence", Journal of Accounting Research, vol. 22: 679-702

Stefaniak, C.M., Houston, R.W. \& Brandon, D.M. (2017) "Investigating inspection risk: An analysis of PCAOB inspections and internal quality reviews", Auditing: A Journal of Practice \& Theory, vol. 36, no. 1: 151-168.

Watts, R.L. \& Zimmerman, J.L. (1986) Positive accounting theory, Prentice Hall, Inc., Englewood Cliffs. 


\section{Appendix A. Definition of Variables}

\begin{tabular}{|c|c|c|}
\hline Variable & Description & Measured by \\
\hline \multicolumn{3}{|c|}{ Panel A - Dependent variables } \\
\hline Lnh & Natural logarithm of total audit hours & $\begin{array}{l}\text { Blokdijk et al. (2006) } \\
\text { Schelleman \& Knechel } \\
(2010)\end{array}$ \\
\hline$P$ & $\begin{array}{l}\text { The ratio of the audit engagement fees to the } \\
\text { engagement costs, with engagement costs } \\
\text { equal to audit hours performed weighted by } \\
\text { hourly cost rates associated with each rank }\end{array}$ & $\begin{array}{l}\text { Schelleman \& Knechel } \\
(2010)\end{array}$ \\
\hline \multicolumn{3}{|c|}{ Panel B - Independent variables } \\
\hline \multicolumn{3}{|c|}{ Client Characteristics } \\
\hline Lnassets & Natural logarithm of client assets & $\begin{array}{l}\text { Schelleman \& } \text { Knechel } \\
\text { (2010) } \\
\text { Bradbury \& Botica } \\
\text { Redmayne (2014) }\end{array}$ \\
\hline Complexity & $\begin{array}{l}\text { An assessment of the engagement complexity by } \\
\text { the respondent on a seven-point Likert scale }(1= \\
\text { simple to } 7=\text { very complex })\end{array}$ & Blokdijk et al. (2006) \\
\hline Public & $\begin{array}{l}\text { Dummy variable equals to one if the client is } \\
\text { publicly listed and zero otherwise }\end{array}$ & $\begin{array}{l}\text { Hackenbrack \& Knechel } \\
\text { (1997) } \\
\text { Bradbury \& Botica } \\
\text { Redmayne }(2014)\end{array}$ \\
\hline ICreliance & $\begin{array}{l}\text { Dummy variable equals to one if the auditor's } \\
\text { reliance on client internal control system is high } \\
\text { and zero otherwise }\end{array}$ & O'Keefe et al. (1994) \\
\hline \multicolumn{3}{|c|}{ Auditor Characteristics } \\
\hline Aud_Size & The number of auditors within the audit firm & Choi et al. (2010) \\
\hline Aud_Spec & $\begin{array}{l}\text { Dummy variable equals to one if the audit firm } \\
\text { is a specialist and zero otherwise }\end{array}$ & Dekeyser et al. (2018) \\
\hline New_Clt & $\begin{array}{l}\text { Dummy variable equals to one if it is a first- } \\
\text { year client and zero otherwise }\end{array}$ & $\begin{array}{l}\text { Schelleman \& Knechel } \\
\text { (2010) }\end{array}$ \\
\hline \multicolumn{3}{|c|}{ Engagement Characteristics } \\
\hline Nas_P & $\begin{array}{l}\text { Dummy variable equals to one if the audit } \\
\text { firm provided NAS to the client in the past } \\
\text { and zero otherwise }\end{array}$ & Knechel et al. (2009) \\
\hline Peak & $\begin{array}{l}\text { Dummy variable equals to one if the } \\
\text { engagement was carried out during the busy } \\
\text { season and zero otherwise }\end{array}$ & Knechel et al. (2009) \\
\hline Interim & $\begin{array}{l}\text { Dummy variable equals to one if interim work } \\
\text { is performed and zero otherwise }\end{array}$ & $\begin{array}{l}\text { Knechel et al. (2009) } \\
\text { Schelleman \& Knechel } \\
(2010)\end{array}$ \\
\hline
\end{tabular}


Determinants of the production and profitability of audit services in Tunisia

\begin{tabular}{|c|c|c|}
\hline Joint_Aud & $\begin{array}{l}\text { Dummy variable equals to one if the engagement } \\
\text { is provided by two auditors and zero otherwise }\end{array}$ & André et al. (2016) \\
\hline \multicolumn{3}{|l|}{ Fees } \\
\hline Lnfees & $\begin{array}{l}\text { The fee paid by the client to an audit firm based } \\
\text { on the calculated proxy }\end{array}$ & Tunisian regulation \\
\hline \multicolumn{3}{|c|}{ Panel C - Control variable } \\
\hline Industry & $\begin{array}{l}\text { Dummy variable equals to one if the client is } \\
\text { a financial services firm and zero otherwise }\end{array}$ & $\begin{array}{l}\text { Hackenbrack \& Knechel } \\
\text { (1997) } \\
\text { Blokdijk et al. (2006) }\end{array}$ \\
\hline
\end{tabular}

\section{Appendix B. Sample items of the questionnaire}

\begin{tabular}{|l|l|l|}
\hline \multicolumn{1}{|c|}{ Section } & \multicolumn{1}{|c|}{ Types of questions } & \multicolumn{1}{c|}{ Sample items } \\
\hline Section (A) & $\begin{array}{l}\text { Engagement } \\
\text { identification } \\
\text { questions }\end{array}$ & $\begin{array}{l}\text {-The engagement industry } \\
\text { - The engagement's financial year. }\end{array}$ \\
\hline Section (B) & Yes-No questions & $\begin{array}{l}\text {-The audit client is listed } \\
\text { - The engagement is joint audit engagement }\end{array}$ \\
\hline Section (C) & $\begin{array}{l}\text {-Scale questions } \\
\text {-Client's financial } \\
\text { statement information } \\
\text { engagement: Not complex at all 1-----> }\end{array}$ \\
\hline Section (D) & $\begin{array}{l}\text { Extremely complex } \\
- \text { The audit client' total assets: ...... } \\
\text { - The audit client' total revenues: ...... }\end{array}$ \\
\hline Section (E) & $\begin{array}{l}\text { Anformation about the team assigned to the } \\
\text { engagement: Enumerating the allocated } \\
\text { auditors, their rank, the number of auditing } \\
\text { hours spent on this engagement, etc. }\end{array}$ \\
\hline
\end{tabular}

